\begin{tabular}{|l|l|l|l|l|}
\hline $\begin{array}{l}\text { Cuadernos de Investigación Geográfica } \\
\text { Geographical Research Letters }\end{array}$ & 2020 & $\mathbf{N}^{\circ} 46(2)$ & pp. 581-602 & eISSN 1697-9540 \\
\hline
\end{tabular}

\title{
TRENDS AND LAND SURFACE PHENOLOGICAL RESPONSES TO CLIMATE VARIABILITY IN THE ARGENTINA PAMPAS
}

\author{
B. LARA ${ }^{1,2 *}$, M. GANDINI ${ }^{1,3}$, P. GANTES ${ }^{4}$, S.D. MATTEUCCI ${ }^{5}$ \\ ${ }^{1}$ Universidad Nacional del Centro de la Provincia de Buenos Aires (UNCPBA), \\ Facultad de Agronomía, Laboratorio de Investigación y Servicios en Teledetección de Azul (LISTA), \\ Av. República de Italia 780, C7300 Azul, Argentina. \\ ${ }^{2}$ Consejo Nacional de Investigaciones Científicas y Técnicas (CONICET), \\ Facultad de Agronomía, Laboratorio de Investigación y Servicios en Teledetección de Azul (LISTA), \\ Av. República de Italia 780, C7300 Azul, Argentina. \\ ${ }^{3}$ Comisión de Investigaciones Científicas (CIC) de la Provincia de Buenos Aires, \\ Facultad de Agronomía, Laboratorio de Investigación y Servicios en Teledetección de Azul (LISTA), \\ Av. República de Italia 780, C7300 Azul, Argentina. \\ ${ }^{4}$ Universidad Nacional de Luján (UNLu), Departamento de Ciencias Básicas, Instituto de Ecología y \\ Desarrollo Sustentable (INEDES-CONICET), Ruta 5 y Av. Constitución, C6700 Luján, Argentina. \\ ${ }^{5}$ Consejo Nacional de Investigaciones Científicas y Técnicas (CONICET), \\ Grupo de Ecología de Paisajes y Medio Ambiente (GEPAMA), Universidad de Buenos Aires, Washington \\ 1821, C1430ETA, Buenos Aires, Argentina.
}

\begin{abstract}
Understanding the interaction between land surface and atmosphere processes is fundamental for predicting the effects of future climate change on ecosystem functioning and carbon dynamics. The objectives of this work were to analyze the trends in land surface phenology (LSP) metrics from remote sensing data, and to reveal their relationship with precipitation and ENSO phenomenon in the Argentina Pampas. Using a time series of MODIS Normalized Difference Vegetation Index (NDVI) data from 2000 to 2014, the start of the growing season (SOS), the annual integral of NDVI( $i$-NDVI, linear estimator of annual productivity), the timing of the annual maximum NDVI ( $t-M A X)$ and the annual relative range of NDVI (RREL, estimator of seasonality) were obtained for the Argentina Pampas. Then, spatial and temporal relationships with the Multivariate ENSO Index (MEI) and precipitation were analyzed. Results showed a negative trend in annual productivity over a 53.6\% of the study area associated to natural and semi-natural grassland under cattle grazing, whereas a 40.3\% of Argentina Pampas showed a significant positive trend in seasonality of carbon gains. The study also reveals that climate variability has a significant impact on land surface phenology in Argentina Pampas, although the impact is heterogeneous. SOS and t-MAX showed a significant negative correlation with the precipitation indicating an earlier occurrence. $23.6 \%$ and $28.4 \%$ of the study area showed a positive correlation of the annual productivity with MEI and precipitation, respectively, associated to rangelands (in the first case) and to both rangeland and croplands, in the second case. Climate variability did not explain the seasonal variability of phenology. The relationships found between LSP
\end{abstract}


metrics and climate variability could be important for implementation of strategies for natural resource management.

\section{Tendencias y respuestas de la fenología de la superficie terrestre a la variabili- dad climática en la Pampa Argentina}

RESUMEN. Comprender la interacción entre los procesos de la superficie terrestre y la atmósfera es fundamental para predecir los efectos del cambio climático futuro sobre el funcionamiento de los ecosistemas y la dinámica del carbono. Los objetivos de este trabajo fueron analizar las tendencias en métricas de la fenología de la superficie terrestre derivadas de sensores remotos, y revelar su relación con la precipitación y el fenómeno ENSO en la región pampeana de Argentina. A partir de una serie temporal de imágenes del Índice de Vegetación de Diferencia Normalizada (NDVI) de MODIS para el período 2000-2014, se obtuvo para la región pampeana de Argentina el inicio de la estación de crecimiento (SOS), la integral anual del NDVI (i-NDVI, estimador lineal de la productividad anual), el tiempo del máximo anual del NDVI (t-MAX) y el rango relativo anual de NDVI (RREL, estimador de la estacionalidad). Posteriormente, se analizaron las relaciones espaciales y temporales con el Índice Multivariado del ENSO (MEI) y la precipitación. Los resultados mostraron una tendencia negativa en la productividad anual en un 53,6\% del área de estudio asociado a zonas de pastizales naturales y semi-naturales, mientras que un 40,3\% de la Pampa Argentina mostró una tendencia positiva significativa en la estacionalidad de las ganancias de carbono. Este estudio también revela que la variabilidad climática tiene un impacto significativo en la fenología de la superficie terrestre de la región pampeana, aunque este impacto es heterogéneo. SOS y t-MAX mostraron una correlación negativa significativa con la precipitación, lo que indica una ocurrencia más temprana. El 23,6\% y 28,4\% del área de estudio mostró una correlación positiva de la productividad anual con el MEI y la precipitación, respectivamente, asociado a pastizales (en el primer caso) y sobre pastizales y áreas agrícolas en el segundo caso. La variabilidad climática no explicó la variabilidad en la estacionalidad de la fenología. Las relaciones encontradas entre las métricas de la fenología de la superficie terrestre y la variabilidad climática podrían ser importantes para la implementación de estrategias para el manejo de los recursos naturales.

Key words: Climate variability, land surface phenology, MODIS, ENSO, carbon gains; Argentina Pampas.

Palabras clave: variabilidad climática, fenología de la superficie terrestre, MODIS, ENSO, ganancias de carbono, región pampeana de Argentina.

Received: 7 July 2019

Accepted: 5 December 2019

*Corresponding author: Bruno Lara, Universidad Nacional del Centro de la Provincia de Buenos Aires (UNCPBA), Facultad de Agronomía, Laboratorio de Investigación y Servicios en Teledetección de Azul (LISTA), Av. República de Italia 780, C7300 Azul, Argentina.E-mail address: bruno.lara@faa.unicen.edu.ar 


\section{Introduction}

Phenology can be defined as the study of the timing of recurrent biological events, the causes of their timing with regard to biotic and abiotic forces, and the interrelation among phases of the same or different species (Lieth, 1974). Vegetation phenology is a key aspect for the global carbon and water cycles, influencing the exchange of energy and water vapor between the atmosphere and land surface (Cong et al., 2013; Luo et al., 2013). In this sense, phenology is one of the most important biological indicators of the effects of climate change on biological systems at different scales (Bertin, 2008; Dai et al., 2013). From the applications of satellite datasets, the concept of land surface phenology (LSP) is often used, referring to the seasonal pattern of variation in vegetated cover that is observed through remote sensing (Helman, 2018; Reed et al., 2009). This approach differs from phenological records of individual species, which refers to events as flowering, senescence, etc. Because LSP is based on observations at larger geographical scales, these metrics reflect the behavior of heterogeneous areas. However, this information is very relevant for understanding and representing landscape-scale processes such as the interaction between the atmosphere and land surface (Friedl et al., 2006). Although it is difficult to provide a sufficiently dense network of phenological events, satellite-derived measures of phenology is an essential approach to include them in carbon dynamics or other more complex climatic models (Müller et al., 2014).

In this context, the increased availability of satellite images has allowed their use in ecology and environmental sciences to characterize landscape heterogeneity and its spatial pattern at very different temporal and spatial scales (Cabello and Paruelo, 2008; Paruelo, 2008; Horning et al., 2010). Recently, remote sensing data have allowed determining functional attributes of ecosystems associated to LSP metrics (Alcaraz-Segura et al., 2009; Lara et al., 2018). Several spectral indices derived from remote sensors have been proposed as estimators of vegetation presence and condition, and these have proved to be useful to analyze surface vegetation characteristics (Tucker, 1979; Helman, 2018; Solano et al., 2010). The theoretical basis for these empirical-based vegetation indices is derived from observation of typical spectral reflectance signatures of leaves. In them, the reflected energy in the visible range of the spectrum is very low due to high absorption by photosynthetically active pigments, with maximum absorption in the blue $(470 \mathrm{~nm})$ and red $(670 \mathrm{~nm})$ wavelengths. Most of the near infrared radiation (NIR) is scattered (transmitted and reflected) with very little absorption due to the mesophyll structure of leaves (Solano et al., 2010). As a result, the contrast between red and NIR responses is a sensitive measure of vegetation amount, with maximum differences over a full canopy and minimal contrast over surfaces with little or no vegetation (Solano et al., 2010). One of the most common ways to quantify the red-NIR contrast is through the use of ratios, where the Normalized Difference Vegetation Index (NDVI) is one of the most widely used (Rouse et al., 1973).

NDVI is a linear estimator of the fraction of photosynthetically active radiation intercepted by vegetation (fAPAR) (Wang et al., 2004). Radiation interception is the main process controlling carbon gains (Monteith, 1981) -a key aspect of ecosystem 
functioning because it represents the energy available for upper trophic levels- and, hence, NDVI has been used as a proxy to describe local and regional patterns of net primary productivity and their interannual variability (Lara et al., 2018; Paruelo et al., 2001; Texeira et al., 2015). From the data provided by satellite sensors of high temporal resolution (i.e. MODIS, AVHRR, MERIS, etc.), NDVI time-series can be constructed to extract valuable information about LSP (Reed et al., 2009). LSP derived from NDVI time-series has been used to evaluate vegetation responses to climatic changes at global scale (Nemani et al., 2003), in determining the importance of climate drivers on phenology in grassland of semi-arid areas in China (Zhu and Meng, 2015) and semi-arid region in Chile (Glade et al., 2016). Additionally, the use of NDVI time-series has allowed to analyze trends and phenology responses to climate variability (Broich et al., 2014; Schmidt et al., 2010; Van Leeuwen et al., 2013; Zhou et al., 2016) and the effects of land cover types (Baldi et al., 2008; Texeira et al., 2015). Recently, long-term NDVI time series have been applied for mapping ecosystem functional diversity (Lara et al., 2018; Wang and Huang, 2015), ecosystem services related to carbon and water dynamics and biodiversity (Paruelo $e t$ al., 2016), and to reveal early-warnings of range shifts and predictions of short-term fluctuations in suitable conditions for some plant species in the Iberian Peninsula (Alcaraz-Segura et al., 2017). According with Kuenzer et al. (2015), the analysis of long-term time series permits revealing the dynamic processes that otherwise might remain hidden to human perception.

As mentioned above, several studies have demonstrated the effects of climate variability on ecosystem functioning and LSP from arid to humid ecosystems at different latitudes (Broich et al., 2004; Hou et al., 2015; Melendez-Pastor et al., 2010; Weiss et al., 2004). The wide variety of land cover types throughout South America (Blanco et al., 2013) is strongly impacted by interannual variability in climate. El Niño Southern Oscillation (ENSO) is the most important coupled ocean-atmosphere phenomenon that causes global climate variability on seasonal to interannual time scales (Wolter and Timlin, 2011). Dessay et al. (2004) have shown the diversity and complexity of the impact of the ENSO over different vegetation types in South America. Particularly for the Argentina Pampas, trends and the responses of phenology to climate variability have been approached from a continental or global perspective, where have been found contrasting results using different satellite datasets (Müller $e t$ al., 2014; Van Leeuwen et al., 2013; Zhang et al., 2017; Zhao and Running, 2010). The Argentina Pampas is the most productive rainfed region of Argentina, and the identification of the relationship between climate variability and phenology would be a fundamental input to predict changes on ecosystem functioning in the context of future global change (IPCC 2013).

The objectives of this research were: (1) to analyze the trends in land surface phenology (LSP) metrics derived from the NDVI time-series for the period 2000-2014, and (2) to reveal the relationships between LSP metrics and precipitation, as well as between LSP metrics and the Multivariate ENSO Index (MEI; Wolter and Timlin, 2011), a proxy of ENSO, in the Argentina Pampas. 


\section{Material and methods}

\subsection{Study area}

The Argentina Pampas is a wide plain located in the centre-east of Argentina (Fig. 1). The climate is humid temperate, with a mean annual precipitation range of 700 $1200 \mathrm{~mm}$ and a mean annual temperature range of $14-20^{\circ} \mathrm{C}$. Precipitation decreases from northeastern to southwestern, and rainfall is mainly distributed in spring and summer. Mean annual temperature decreases from north to south (Matteucci, 2012). The interannual variability of precipitation regime determines occasional extreme conditions of floods and droughts over wide zones (Viglizzo et al., 1997). This variability is -in part- linked to El Niño and La Niña events that impact differentially throughout the study area (Aliaga et al., 2016).

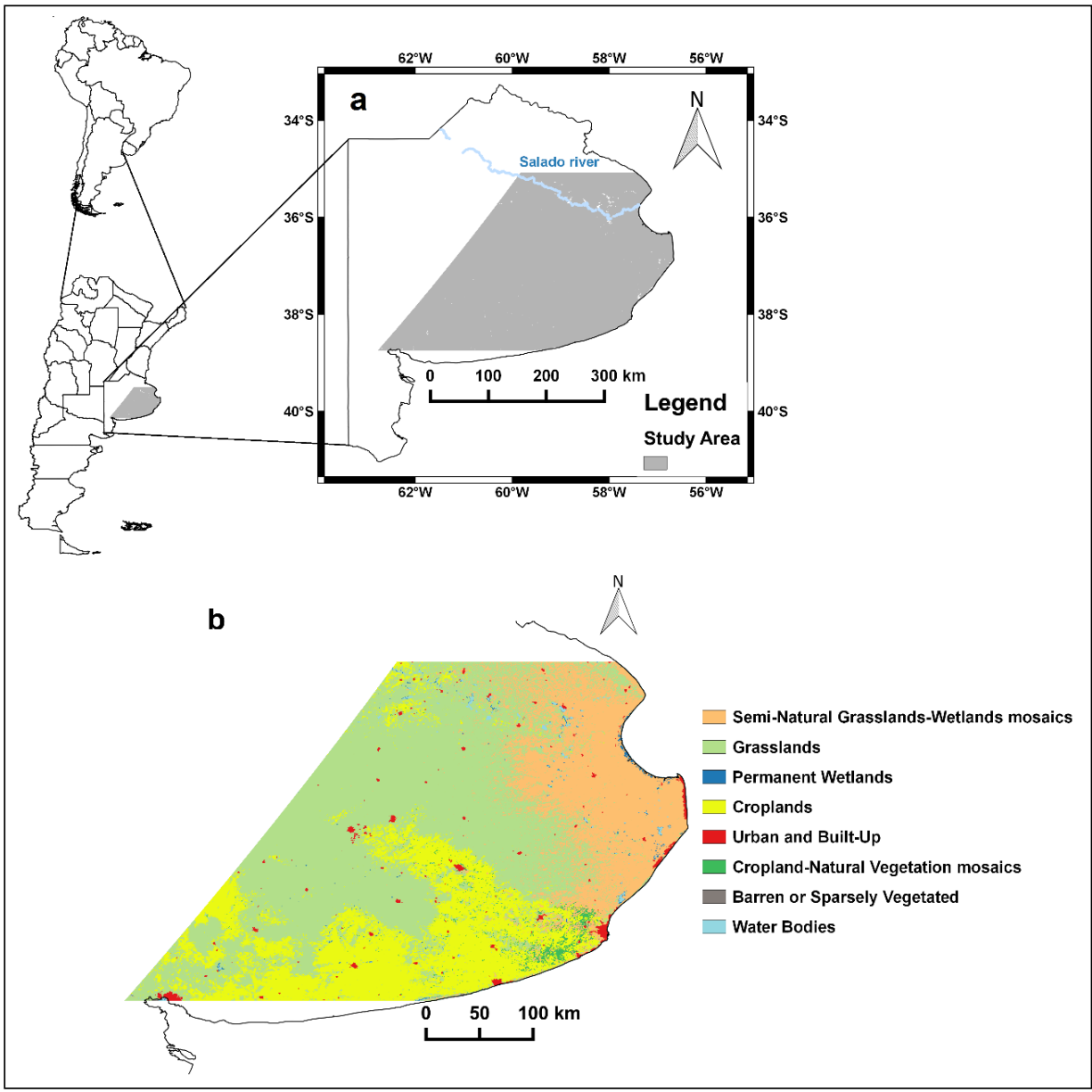

Figure 1. (a) Location of the study area. (b) Main land cover types in the Argentina Pampas. 
The Argentina Pampas, which supports one of the largest temperate grasslands on the globe, is characterized by high heterogeneity of landscapes. This region has undergone major changes since the sixteenth century (Lara and Gandini, 2014; Matteucci, 2012). In this context, favorable climate and soil conditions have converted the Argentina Pampas in the most productive rainfed region of Argentina. For example, in the agricultural year 2012/2013, this region produced 43 million tons of soybean and maize, which represent $88 \%$ of the country's total (Arrieta et al., 2018). Particularly during the last 25-30 years the Argentina Pampas has experienced a process called "agriculturization", characterized by an increase in the cultivated areas in traditional livestock use or mixed areas. This process is mainly sustained by structural economic changes and the inclusion of technological packages associated with the cultivation of genetically modified soybean (ManuelNavarrete et al., 2009; Viglizzo et al., 2011). As a result, the agriculture is based on a few crops: soybean and maize as summer crops, and wheat and barley as winter crops. Where the agriculture is not practicable, natural or semi-natural grassland under cattle grazing represents the main natural vegetation type (Lara and Gandini, 2014; Gandini et al., 2019).

\subsection{Remote sensing data and extraction of phenological metrics}

Our study was based on a 14-year (2000-2014) NDVI dataset obtained from satellite images. MOD13Q1 product (version 6) from Terra's Moderate Resolution Imaging Spectroradiometer (MODIS) was used. This dataset consists of a 16-day maximum value composite obtained by the Constrained View angle-Maximum Value Composite (CVMVC) and Maximum Value Composite (MVC) techniques. The scenes have a spatial resolution of $250 \times 250 \mathrm{~m}$. The dataset used covers the period July 2000 (Julian day 177) to June 2014 (Julian day 161). Despite the fact that the temporal window does not align with calendar years, this range retrieves the main Southern Hemisphere growing seasons.

NDVI time-series are affected by clouds and aerosols, which add noise to the signal sensor and does not allow the direct extraction of phenological metrics. To overcome this problem, several smoothing functions are used to remove noise introduced by undetected clouds and poor atmospheric conditions (Atkinson et al., 2012; Atzberger and Eilers, 2011; Zhu and Meng, 2015). In this work, an adaptive Savitzky-Golay filter was applied using TIMESAT software v3.2 (Jönsson and Eklundh, 2004) since it has showed a balanced ability to reduce noise while maintaining the NDVI time-series integrity in our study area (Lara and Gandini, 2016). Furthermore, the pixel reliability band was used to weight each pixel in the time series: value 0 (good data) had full weight (1.0), values 1-2 (marginal data, snow/ice) had half weight (0.5) and value 3 (cloudy) had low weight (0.1). Once NDVI time-series was smoothed, four phenological metrics were obtained for each growing season for the period 2000-2014: the start of the growing season (SOS), the annual integral of NDVI (i-NDVI), the timing of the annual maximum NDVI (t-MAX) and the annual relative range of NDVI (RREL) (Lara et al., 2018). SOS corresponds to the day of year in which vegetation starts its annual activity and mathematically is associated with the time for which the NDVI increases a certain fraction of the seasonal amplitude (difference between maximum and minimum NDVI for one growing season). Based on previous works (Lara and Gandini, 2016; Lara et al., 2018) a threshold of 20\% of the amplitude 
was considered to determine the start of the growing season. i-NDVI is a proxy for the net primary productivity for each growing season (sum of positive NDVI values over a growing season); t-MAX corresponds to the day of year where the maximum NDVI value occurs within a year and it is related to the period of maximum photosynthetic activity; and RREL is a descriptor of seasonality and it is associated with the intra-annual variation of light interception during the growing season. RREL is obtained from the difference between the maximum and minimum NDVI values (seasonal amplitude) divided by i-NDVI. In contrast with seasonal amplitude, RREL allows comparing the seasonality of different pixels independently of the ecosystem analyzed (Alcaraz-Segura et al., 2009).

\subsection{Trends of phenological metrics}

The Mann-Kendall trend test was used to evaluate monotonic temporal trends in the time series of phenological metrics. This statistical procedure is a robust rank-based nonparametric test against missing values, non-normality, and temporal autocorrelation (Helsel and Hirsch, 2002). The Mann-Kendall test assesses the presence of a monotonic time trend based on the Kendall's tau statistic, where all combinations of pairs of values over time are evaluated in each pixel, and a count of the number of times it increases or decreases over time is obtained. The Kendall's tau statistic is simply the relative frequency of the increments minus the relative frequency of the decreases. In this work, an alpha level equal to 0.05 was used and thus slopes with a $P$-value $<0.05$ were defined as statistically significant.

\subsection{Climate datasets}

Monthly values of the Multivariate ENSO Index (MEI) were used as a proxy to ENSO phenomenon (Wolter and Timlin, 2011). In contrast with other commonly used indexes (e.g. SOI, NINO 3.4, etc.), the MEI provides for a more complete and flexible description of the ENSO phenomenon because it is based on six different variables: sea level pressure, zonal and meridional surface wind components, sea surface temperature, near-surface air temperatures, and total cloudiness (Wolter and Timlin, 2011). Positive values of MEI are associated with El Niño and negative values are associated with La Niña phases.

Due to the fact that the winter period is a critical climate factor that affects interannual variability of phenology (Wang et al., 2015), mean tri-monthly MEI values of July-September were calculated for each growing season.

The effects of interannual variability of precipitation regimes have been seen over Uruguay (Texeira et al., 2015), and it is to be expected that something similar occurs in the Argentina Pampas. However, observations over South America, and particularly over the Argentina Pampas, are insufficient and unevenly distributed. In this sense, the estimation of precipitation derived from remote sensors provides essential information in areas where rain gauge datasets are insufficient. For central Argentina and Uruguay, Salio et al. (2015) demonstrated a good performance of Tropical Rainfall Measuring Mission (TRMM) products in the estimation of precipitation. We used monthly data from the TRMM product 3B43 with a $0.25^{\circ} \times 0.25^{\circ}$ spatial resolution for the period $2000-2014$. The precipitation rates $(\mathrm{mm} / \mathrm{h})$ were converted to total monthly precipitation. In order to compare with the mean tri-monthly 
MEI values of July-September, accumulated precipitation during August-October period were calculated for each growing season. This temporal difference is due to the response time for the global atmosphere to tropical anomalies (Wolter and Timlin, 2011).

\subsection{Spatial phenological responses to MEI and precipitation}

We applied a first order linear regression analysis to evaluate the relationship between LSP metrics and MEIs values and precipitation for the period 2000-2014. The following equation represents the relationship between LSP metrics and mean trimonthly MEI values of July-September on a pixel to pixel analysis:

$$
L S P_{\text {metric }}=a * M E I_{w}+b+e
$$

where $L S P_{\text {metric }}$ represents the different land surface phenological metrics derived from NDVI time-series (SOS, i-NDVI, t-MAX and RREL), $a$ is the slope coefficient for, $b$ is the intercept regression, and $e$ is the error term of the least squares solution.

In the same way, the following equation represents the relationship between LSP metrics and accumulated precipitation on a pixel to pixel analysis:

$$
L S P_{\text {metric }}=a * P P_{a c c}+b+e
$$

where $L S P_{\text {metric }}$ represents the different land surface phenological metrics derived from NDVI time-series (SOS, i-NDVI, t-MAX and RREL), $a$ is the slope coefficient for $P P_{a c c}$, $b$ is the intercept regression, and $e$ is the error term of the least squares solution.

For both models, alpha levels equal to 0.05 were used and thus slopes with a $P$-value $<0.05$ were defined as statistically significant. In order to consider autocorrelation, the Durbin-Watson test was applied on residual time-series (Durbin and Watson, 1951). Although autocorrelation in the residuals has no impact on the lineal model correlation $(r)$, the estimation of statistical significance may be exaggerated because the estimated variance of $r$ will tend to be too small. Then a significant relationship could be reported when it is not insured. The Durbin-Watson test is the standard method for detecting autocorrelation in regression models. This procedure is based on the critical values of Durbin-Watson statistic (d), which for these cases (linear regression analysis for a period of 14 years) are 1.35 and 2.65 as minimum and maximum values respectively (Durbin and Watson, 1951).

\section{Results}

\subsection{Mean spatial patterns and trends of land surface phenology in the Argentina Pampas}

The mean spatial patterns of land surface phenological metrics analyzed and their temporal trends are shown in Figure 2. Most of the SOS values occur on days of year (DOY) 213-263 (August-September), whereas in the southwestern region SOS occurs on DOY 274344 (October-November) (Fig. 2a). Almost the entire study area $\left(91.4 \% ; 12,9641.0 \mathrm{~km}^{2}\right)$ lack a significant SOS trend, while $7.1 \%$ of the study area $\left(10,025.4 \mathrm{~km}^{2}\right)$ showed a positive trend implying a delay of SOS (Fig. 2b). Only a minimal portion of the study area (1.5\%; $2081.6 \mathrm{~km}^{2}$ ) showed a negative trend, indicating an earlier SOS during the period 2000-2014. 


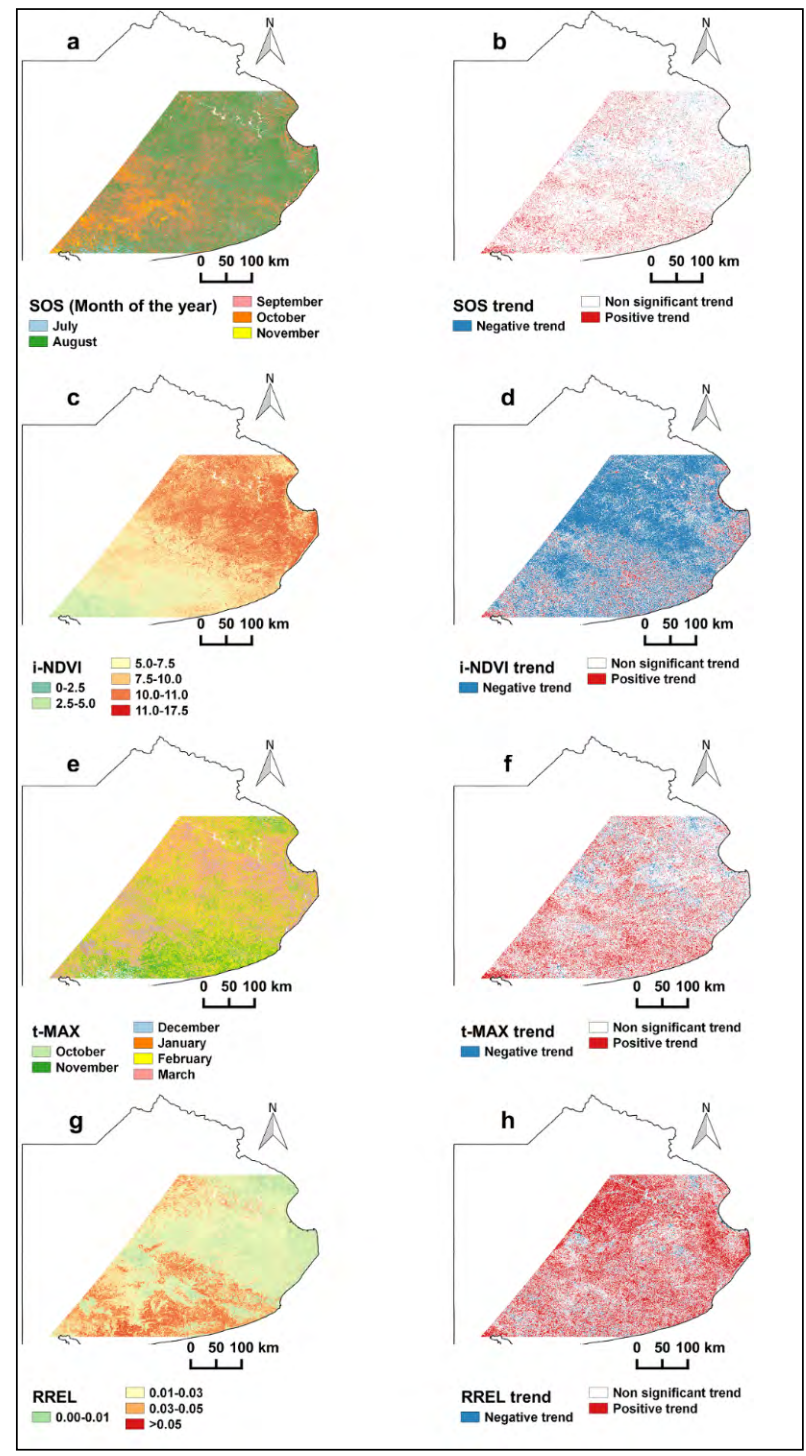

Figure 2. Mean (2000-2014) values of the start of the growing season (SOS), annual productivity $(i-N D V I)$, the timing of the annual maximum NDVI ( $t-M A X)$ and seasonality (RREL) are shown in $(a),(c),(e)$ and $(g)$, respectively. Significant trends based on Mann-Kendall test for SOS, $i$-NDVI, $t$-MAX and RREL are shown in $(b),(d),(f)$, and $(h)$, respectively.

The i-NDVI mean values (linear estimator of net primary productivity) increased from the southwestern to the northeastern regions (Fig. 2c). 53.6\% of the study area showed a significant negative trend in i-NDVI during the period 2000-2014, representing a surface of $76,035.4 \mathrm{~km}^{2}$ mainly located in the centre of our study area (Fig. 2d). On the other hand, 
$7.6 \%$ of the area $\left(10,783.4 \mathrm{~km}^{2}\right)$ showed positive i-NDVI trends on the southern region. The remnant surface, $54929.3 \mathrm{~km}^{2}(38.8 \%)$, did not show a significant productivity trend.

In much of the study area, the mean peak of NDVI (t-MAX) occurred in late summer (February-March; Fig. 2e), whereas in the southern and northeastern pampas, the mean annual maximum of NDVI was observed earlier (between October-November). $21.8 \%$ of the study area $\left(30,895.2 \mathrm{~km}^{2}\right)$ showed a significant positive trend in t-MAX implying a delay of the period of maximum photosynthetic activity (Fig. 2f), whereas only $5.4 \%$ of the area $\left(7593.5 \mathrm{~km}^{2}\right)$ displayed a negative trend indicating an earlier t-MAX across the period 2000-2014. Most of the positive trends were observed on south and southwestern pampas, a typical agricultural area for winter crops.

Mean RREL for the period 2000-2014 presented a contrasting spatial pattern with i-NDVI, where areas that showed a higher productivity (i-NDVI) presented a lower seasonality (RREL), and vice versa (Fig. $2 \mathrm{~g}$ ). $40.3 \%$ of the study area $\left(57,011.3 \mathrm{~km}^{2}\right)$ showed a significant positive trend in RREL during the period 2000-2014, whereas only $4.7 \%$ of the study area $\left(6721.8 \mathrm{~km}^{2}\right)$ showed negative RREL trends (Fig. $2 \mathrm{~h}$ ). The remaining $55.0 \%$ of the surface had no significant RREL trend. These negative trends did not show a definite spatial pattern. However, positive trends in RREL were mainly located at north, south and east of our study area.

\subsection{Relationship between land surface phenological metrics and MEI variability and precipitation}

Residual time-series for the relationship between land surface phenological metrics and climate variability (MEI and accumulated precipitation) showed no autocorrelation (Table 1).

Table 1. Mean values of Durbin-Watson statistic (d) for residual time-series derived from both linear regression analyses: between phenological metrics and Multivariate ENSO Index values $(d 1)$, and between phenological metrics and accumulated precipitation (d2). $d$ values between 1.35 and 2.65 indicate no autocorrelation (standard deviation values are shown in parentheses). SOS: start of the growing season; $i$-NDVI: annual integral of NDVI; $t$-MAX: timing of the annual maximum NDVI; RREL: annual relative range of NDVI.

\begin{tabular}{|c|c|c|c|c|}
\hline \multirow{2}{*}{} & \multicolumn{4}{|c|}{ Land Surface phenological metrics } \\
\cline { 2 - 5 } & SOS & i-NDVI & t-MAX & RREL \\
\hline$d 1$ & $1.94(0.55)$ & $1.83(0.53)$ & $1.94(0.59)$ & $1.84(0.55)$ \\
\hline$d 2$ & $1.94(0.53)$ & $1.82(0.51)$ & $1.97(0.55)$ & $1.83(0.53)$ \\
\hline
\end{tabular}

It was not observed a strong spatial pattern with significant phenological response between SOS and MEI (Fig. 3a). Only $12.1 \%$ of the study area $\left(17,175.4 \mathrm{~km}^{2}\right)$ showed a positive correlation with MEI implying a later SOS during El Niño phase and an earlier SOS during La Niña phase; whereas a 5.1\% showed a significant negative correlation, indicating an earlier SOS during El Niño phase and a later SOS during La Niña phase. On the other hand, a $23.7 \%$ of the study area $\left(33,578.9 \mathrm{~km}^{2}\right)$ showed a negative correlation between SOS and accumulated precipitation, suggesting an earlier SOS with more precipitation during August-October (Fig. 3b). This spatial pattern is mainly located 
in the southwestern region. Only $9.3 \%$ of the surface area $\left(13,162.5 \mathrm{~km}^{2}\right)$ showed a significant positive correlation between SOS and accumulated precipitation.

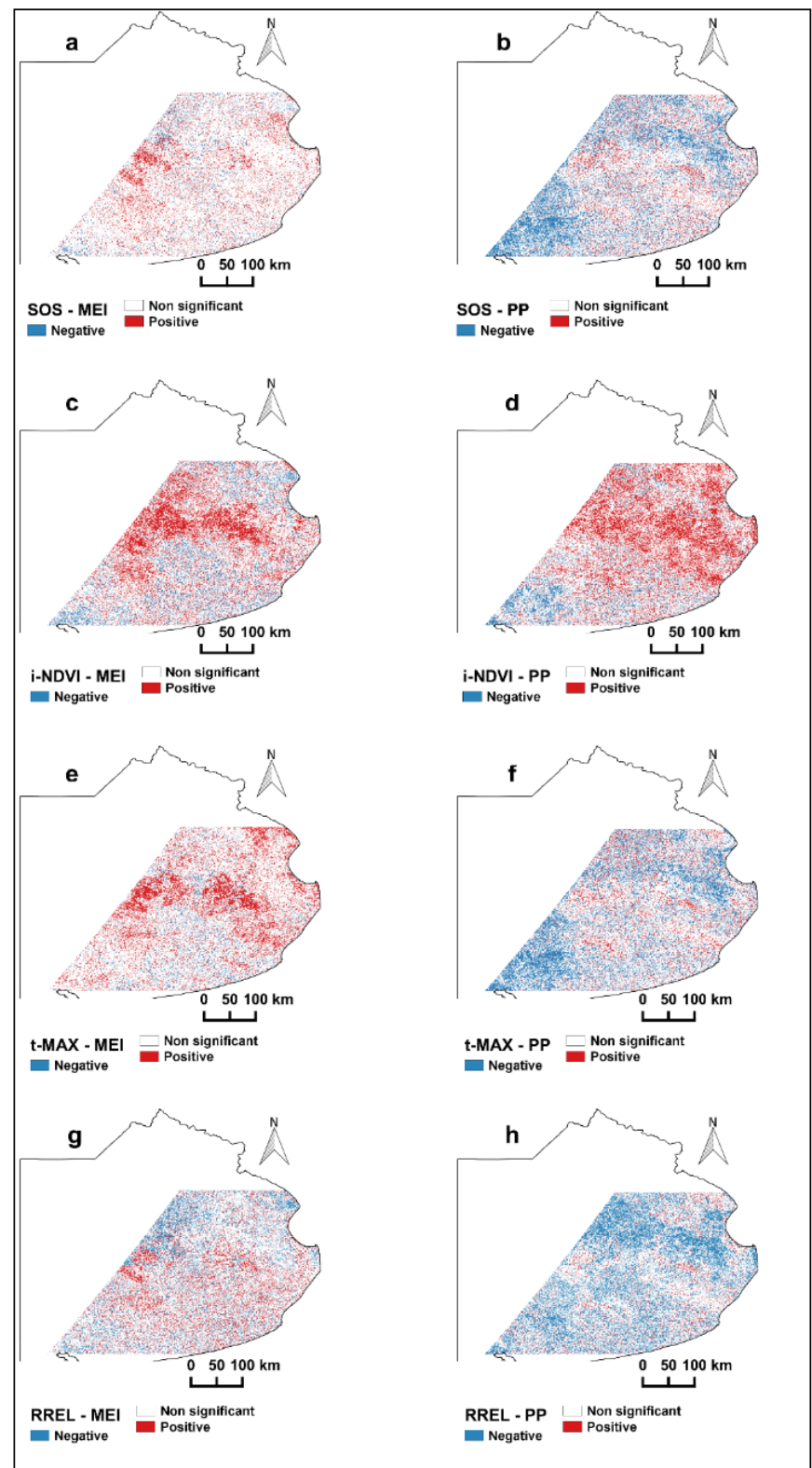

Figure 3. Spatial patterns of significant correlations between land surface phenological metrics and the Multivariate ENSO Index (MEI, left hand side) and with accumulated precipitation (PP, right hand side). SOS: start of the growing season, $i$-NDVI: annual productivity, $t$-MAX: the timing of the annual maximum NDVI, and RREL: seasonality. 
The MEI is both positively and negatively correlated with i-NDVI in our study area, suggesting a higher and lower annual productivity during El Niño phase, respectively. A stronger spatial pattern was associated to a higher annual productivity during El Niño phase (i.e. positive correlation between i-NDVI and MEI), which covered an extensive central strip that can be observed from western to eastern except in the region influenced by Atlantic Ocean (Fig. 3c). This spatial pattern represented a 23.6\% (33,518.8 $\left.\mathrm{km}^{2}\right)$ of the study area. Besides, an isolated pattern of $15,229.6 \mathrm{~km}^{2}(10.7 \%$ of the study area), expanding over south, southwestern and northeastern lands, was observed. It is associated to a lower annual productivity during El Niño phase (i.e. negative correlation between i-NDVI and MEI). Similar to the relationship between i-NDVI and MEI, the spatial relationship between i-NDVI and accumulated precipitation showed positive and negative correlation values across the study area (Fig. 3d). However, the spatial pattern of positive correlation between i-NDVI and accumulated precipitation extended, besides the central region, over the north and northeastern regions occupying a surface of $40,310.3 \mathrm{~km}^{2}$ (28.4\% of the study area). The region associated to a lower annual productivity (negative correlation between i-NDVI and accumulated precipitation) was concentrated mainly in the southwestern of the study area, representing a $9.1 \%$ $\left(12,907.4 \mathrm{~km}^{2}\right)$.

Almost $30 \%$ of the study area exhibited significant correlation between the timing of the annual maximum NDVI (t-MAX) and MEI and accumulated precipitation (Fig. 3e and $3 \mathrm{f}$, respectively). First, most of the significant correlation between t-MAX and MEI was positive $\left(20.9 \%\right.$ of the study area or $29,509.1 \mathrm{~km}^{2}$ ) indicating a later t-MAX during El Niño phase and an earlier t-MAX during La Niña phase. This relationship was located in central-west of Argentina Pampas. Only a $6.0 \%$ of the study area $\left(8542.3 \mathrm{~km}^{2}\right)$ showed a negative correlation between t-MAX and MEI indicating an earlier t-MAX during El Niño phase and a later t-MAX during La Niña phase. Second, most of the significant correlation between t-MAX and accumulated precipitation was negative $(24.3 \%$ of the study area or $34,461.5 \mathrm{~km}^{2}$ ), whereas $13,207.7 \mathrm{~km}^{2}$ (9.3\% of the study area) showed a positive relationship between t-MAX and precipitation. The negative strongest spatial relationship between the timing of the annual maximum NDVI and precipitation was found at southwestern and northeastern of Argentina Pampas (Fig. 3f).

It was not found a strong spatial pattern with significant phenological response between RREL and MEI (Fig. 3g). Only 14.5\% of the Argentina Pampas $\left(20,459.2 \mathrm{~km}^{2}\right)$ showed a positive correlation with MEI indicating a higher difference between maximum and minimum NDVI values within the growing season in El Niño phase, whereas a $14.9 \%$ of the study area $\left(21,135.7 \mathrm{~km}^{2}\right)$ showed a significant negative correlation implying a lower seasonality during El Niño phase. On the other hand, the majority of significant correlations between RREL and accumulated precipitation during August-October period were negative, representing a $30.4 \%$ of the study area $\left(42,970.1 \mathrm{~km}^{2}\right.$; Fig. 3h). This relationship indicates a decrease in seasonality caused by an increase in accumulated precipitation, and it was observed mainly on southwestern and northern regions of Argentina Pampas. Only 5.9\% of the study area $\left(8421.7 \mathrm{~km}^{2}\right)$ showed a significant positive correlation between seasonality and accumulated precipitation. 
In the Argentina Pampas, positive and negative slopes (for MEI and accumulated precipitation) were observed (see Table A1 in Supplementary data). In zones with a positive relationship between MEI and annual productivity (i-NDVI, see Figure $3 \mathrm{c}$ ), according to the regression model, an increase of $0.01 \mathrm{MEI}$ units would increase productivity by 0.064 NDVI values representing $0.689 \%$ of the mean annual productivity. In zones with a negative relationship between MEI and annual productivity, an increase of $0.01 \mathrm{MEI}$ units would decrease productivity by $0.057 \mathrm{NDVI}$ values, representing $0.609 \%$ of the mean annual productivity (see Table A1 and Figure A1c in Supplementary data). On the other hand, in zones with a positive relationship between accumulated precipitation and annual productivity (Fig. 3d), each additional $\mathrm{mm}$ /August-October would increase productivity by 0.016 NDVI values, representing $0.168 \%$ of the mean annual productivity. In zones with a negative relationship between accumulated precipitation and annual productivity, each additional mm/AugustOctober would decrease productivity by 0.014 NDVI values, representing $0.156 \%$ of the mean annual productivity (see Table A1 and Figure A1d in Supplementary data). Similar to the i-NDVI, the regression slopes between ecosystem seasonality (RREL) MEI and accumulated precipitation had negative and positive values (see Table A1 in Supplementary data). According to the regression model, an increase of 0.01 MEI units would increase seasonality by 0.0003 units of NDVI ( $0.931 \%$ of the mean seasonality) where a positive relationship between MEI and seasonality was observed. In contrast, in zones with a negative relationship between MEI and seasonality, the mean slope regression coefficient was -0.0003 representing a $0.929 \%$ of the mean seasonality (see Figure A1g in Supplementary data). The mean slopes regression coefficient between accumulated precipitation and seasonality were of equal absolute value (0.00008), but of opposite sign. In areas with positive relationship, each additional mm/AugustOctober would increase seasonality by $8.10^{-5}$ units of NDVI; whereas in areas with negative relationship each additional $\mathrm{mm} /$ August-October would decrease seasonality by $8.10^{-5}$ units NDVI. These values represent a $0.243 \%$ of the mean seasonality (see Figure A1h in Supplementary data).

\section{Discussion}

Our study characterized interannual trends of land surface phenological metrics in the Argentina Pampas using MODIS-NDVI time-series for the period 20002014. Also, the relationships between these land surface phenological metrics and variability in precipitation and ENSO phenomenon were identified. One of the main findings is the presence of negative trends in annual productivity (i-NDVI) over a 53.6\% of Argentina Pampas. This decrease in annual productivity was strongly associated to natural or semi-natural grassland under cattle grazing, a region known as Flooding Pampa (Lara and Gandini, 2014). Despite the fact that natural or seminatural grassland is the main land cover in Flooding Pampa (Gandini et al., 2019), a noticeable increment of croplands during the last 20 years have been observed (Mestelan and Ramaglio, 2011; Rojas et al., 2011). This process was accompanied by an increment of livestock numbers that has doubled the historical values (Rojas et al., 2011). Therefore, the transformation of rangelands into croplands and an 
increment of livestock number could be associated to higher grazing pressure on the grassland remnants. Probably, the overgrazing on natural grassland is the most relevant phenomenon in causing negative trends in annual productivity. Negative trends in annual productivity (estimated from annual integral of NDVI) in this region are the first evidence found from remote sensing data to regional scale (Baldi et al., 2008; Paruelo et al., 2004; Van Leeuwen et al., 2013). Our results agree with negative trends in annual productivity observed across Argentina Pampas in studies carried out at global scales in similar periods (Zhang et al., 2017; Zhao and Running, 2010).

On the other hand, in the southern region -a typical agricultural area of winter crops- a weak spatial pattern of positive trends in annual productivity was observed. Also, positive trends in seasonality and the timing of the annual maximum NDVI in this region were found. One possible explanation could be associated to the implementation of summer crops immediately after harvest of the winter crop, a practice that have increased in the last years in this region (Forján and Manso, 2012). Double-crop systems increase annual productivity (compared with only one crop) and are associated with a later timing of the annual maximum of NDVI (t-MAX) and higher seasonality (Guerschman et al., 2003). For example, in three emblematic counties of southern Argentina Pampas (Adolfo Gonzales Chaves, San Cayetano and Tres Arroyos), a decrease of $23.4 \%$ of winter crops accompanied with an increase of $16.2 \%$ of summer crops during the period 2000-2014 were observed (Table 2). Both decreasing of winter crops and increasing of summer crops was not uniformly distributed. Wheat was the main winter crop that decreased in surface (from 560,950 ha to $219,880 \mathrm{ha}$ ), whereas barley was the one that increased (from 41,500 ha to 147,400 ha). Within the summer crops, soybean showed a noticeable increase between the agricultural years 2000/2001 (51,500 ha) and 2013/2014 (437,300 ha) (Table 2). The anticipated harvest of barley compared to wheat allows for a lower loss of potential yield of the following summer crop, particularly soybean (Forján and Manso, 2012). Therefore, increasing of the above-mentioned sown areas is associated with an increase of the barley-soybean double crop system on the southern Argentina Pampas.

Table 2. Sown area for main winter and summer crops on three emblematic counties of southern Argentina Pampas, for the 2000/2001 and 2013/2014 agricultural years. *Data obtained from the Integrated Agriculture Information System (IAIS) of the Ministry of Agroindustry of Argentina.

\begin{tabular}{|c|c|c|c|c|c|c|c|c|c|}
\hline & \multirow{3}{*}{ Crop } & \multirow{2}{*}{\multicolumn{2}{|c|}{$\begin{array}{c}\begin{array}{c}\text { Adolfo Gonza- } \\
\text { les Chaves }\end{array} \\
\text { Sown area }(h a)^{*}\end{array}$}} & \multirow{2}{*}{\multicolumn{2}{|c|}{\begin{tabular}{|c|} 
Tres Arroyos \\
Sown area (ha)* \\
\end{tabular}}} & \multirow{2}{*}{\multicolumn{2}{|c|}{$\begin{array}{c}\text { San Cayetano } \\
\text { Sown area (ha)* }\end{array}$}} & \multirow{2}{*}{\multicolumn{2}{|c|}{$\begin{array}{c}\text { Total sown area } \\
\text { (ha)* }\end{array}$}} \\
\hline & & & & & & & & & \\
\hline & & $00 / 01$ & $13 / 14$ & $00 / 01$ & $13 / 14$ & $00 / 01$ & $13 / 14$ & $00 / 01$ & $13 / 14$ \\
\hline \multirow{3}{*}{ Winter crop } & Oat & 11000 & 13000 & 9500 & 14100 & 4500 & 5600 & 25000 & 32700 \\
\hline & Wheat & 161050 & 54100 & 267200 & 119000 & 132700 & 46780 & 560950 & 219880 \\
\hline & Barley & 5000 & 11300 & 31500 & 85500 & 5000 & 50600 & 41500 & 147400 \\
\hline \multirow{3}{*}{ Summer crop } & Sunflower & 42000 & 1400 & 100500 & 25600 & 50500 & 20000 & 193000 & 47000 \\
\hline & Maize & 5500 & 9700 & 40500 & 31000 & 9500 & 14200 & 55000 & 54900 \\
\hline & Soybean & 21500 & 110100 & 22000 & 225300 & 8000 & 101900 & 51500 & 437300 \\
\hline
\end{tabular}


Significant trends observed for the period 2000-2014 suggest changes in the exchange of matter and energy between the biosphere and the atmosphere with high impacts on ecosystem functioning. Particularly a negative trend in carbon gains (annual productivity) and a positive trend in seasonality would be indicating serious effects on biodiversity at ecosystem scale and for the provision of several ecosystem services (Paruelo et al., 2016; Vitousek et al., 1997). Land cover changes or the intensification of productive practices seem to be the responsible for the changes mentioned, or they indicate different works carried out at a more detailed scale (Baldi et al., 2006; GuevaraOchoa et al., 2018; Lara and Gandini, 2014; Vazquez and Zulaica, 2013). These processes reveal a strong component of human control on seasonal carbon dynamics and on ecosystem functioning. However, greater efforts should focus on mapping land cover changes and their transitions at various temporal and spatial scales in the Argentina Pampas. The identification of driving forces, both environmental and socioeconomic, associated to the spatial distribution of land cover changes, would allow the analysis of possible future scenarios and their impacts on ecosystem functioning.

The MEI, a proxy of ENSO variability, and precipitation explain certain LSP metrics variability for some regions in the Argentina Pampas. The stronger spatial relationships between SOS, t-MAX and accumulated precipitation were found at southwestern of Argentina Pampas, a region where the precipitation appears as the main limiting factor for croplands (Andrade et al., 2009). These spatial relationships were negative, implying an earlier SOS and t-MAX with more precipitation during August-October. Similar results have been found for croplands in Australia (Broich et al., 2014). The Southwestern Argentina Pampas is characterized by high interannual variations of SOS and t-MAX, ranging from five to six months (Lara et al., 2018). These results could be indicating the need for management strategies that take advantage of the eventual surplus of soil water.

Although MEI and precipitation did not explain seasonality variability, they did show significant relationship with the annual productivity (estimated by i-NDVI). A positive relationship between annual productivity and MEI on central Argentina Pampa (Flooding Pampa) was found. Natural and semi-natural grassland mosaics that are the main land cover seem responding quickly during warm ENSO events (positive values of $\mathrm{MEI}$ ). In general, the warm ENSO phase is linked to an increase of precipitation (Allan et al., 1996; Podestá et al., 1999). These results are consistent with Schmidt et al. (2010) who found an increase in productivity of grassland and savanna biomes in Australia, and with Dessay et al. (2004) who showed that grasslands in southern Brazil responded with positive anomalies in NDVI values during warm ENSO events. On the other hand, positive relationship between annual productivity and accumulated precipitation was more extended than positive relationship between productivity and MEI. Additionally, this pattern of response extended to the north and northeastern of our study area, where croplands are dominant. Many authors have reported increasing productivity (or similar proxy variables) associated to precipitation variability in grassland and rainfed agricultural areas (Broich et al., 2014; Glade et al., 2016; Podestá et al., 1999; Schmidt et al., 2010; Texeira et al., 2015), accentuating the fact that rainfall play a fundamental role for vegetation growth. 
Key findings are the differences of response patterns between some phenological metrics and MEI, and with precipitation variability. Strong relationships in some regions of Argentina Pampas for SOS and t-MAX only with precipitation could suggest a shortterm effect caused by an increase in precipitation regimes. On the other hand, ENSO events showed a strong relationship with annual productivity indicating long-term effects. One possible explanation could be that MEI is a generic proxy of climatic variability that not only has an influence on precipitation patterns, but also on temperature and solar radiation. In this sense, ecosystems of Argentina Pampas are limited not only by water availability, but also by radiation and temperature (Nemani et al., 2003).

Our study highlights a direct link between land and atmospheric processes. Recent advances in understanding of ocean-atmosphere interactions have made it possible to forecast the occurrence of ENSO events with lead times of several months (Barnston and Tippet, 2013). Results showed here could be relevant for the implementation of strategies for natural resource management such as adjusting livestock numbers or consider more flexible management in croplands. In addition, results could be relevant for monitoring changes in the provision of ecosystem services linked to carbon gains (Paruelo et al., 2016). However, these objectives will require further research and an adequate group of decision-support tools. In this sense, other components associated to climate variability over South America, such as the Antarctic Oscillation and the Pacific Decadal Oscillation (Garreaud et al., 2009), should be incorporated in future works.

\section{Conclusions}

The Argentina Pampas is one of the major agriculture regions in the world, and the understanding of the relationship between land and atmospheric processes is a key feature for applying sustainable management strategies. At regional scale, MODIS-NDVI time series allowed us to assess the trends of a set of land surface phenological metrics. Negative and positive temporal trends in productivity and seasonality, respectively, indicate a strong impact on radiation interception, the main process controlling carbon gains. Our study demonstrated that interannual variability of land surface phenology is related significantly by climate variability. Particularly the relationships between ENSO and accumulated precipitation with annual productivity over large areas of Argentina Pampas provide a fundamental opportunity for predicting the effect of future climate change on carbon dynamics and could be a baseline for the implementation of spatially explicit management policies.

\section{Acknowledgments}

This work was supported on a CONICET doctoral and post-doctoral fellowships (B. Lara) and grants from Research Investigations Council of Buenos Aires Province (CICPBA) and SECyT-UNCPBA (03/A223).

Special thanks to my grandmother "Abuela Sara" who taught me to never give up. You will always be in my heart. This and everything is for you. 


\section{References}

Alcaraz-Segura, D., Cabello, J., Paruelo, J.M., Delibes, M. 2009. Use of descriptors of ecosystem functioning for monitoring a national park network: a remote sensing approach.Environmental Management 43, 38-48. https://doi.org/10.1007/s00267-008-9154-y.

Alcaraz-Segura, D., Lomba, A., Sousa-Silva, R., Nieto-Lugilde, D., Alves, P., Georges, D., Vicente, J.R., Honrado, J.P. 2017. Potential of satellite-derived ecosystem functional attributes to anticipate species range shifts. International Journal of Applied Earth Observation and Geoinformation 57, 86-92. https://doi.org/10.1016/j.jag.2016.12.009.

Aliaga, V.S., Ferrelli, F., Alberdi-Algañaraz, E.D., Bohn, V.Y., Piccolo, M.C. 2016. Distribución y variabilidad de la precipitación en la región pampeana, Argentina. Cuadernos de Investigación Geográfica 42, 261-280. https://doi.org/10.18172/cig.2867.

Allan, R., Lindesay, J., Parker, D. 1996. El Niño Southern Oscillation and climate variability. CSIRO Publishing, Collingwood, Australia.

Andrade, M.I., Laporta, P., Iezzi, L. 2009. Sequías en el sudoeste bonaerense: Vulnerabilidad e incertidumbre. Geograficando 5, 213-233.

Arrieta, E.M., Cuchietti, A., Cabrol, D., González, A.D. 2018. Greenhouse gas emissions and energy efficiencies for soybeans and maize cultivated in different agronomic zones: a case study of Argentina. Science of the Total Environment 625, 199-208. https://doi.org/10.1016/j. scitotenv.2017.12.286.

Atkinson, P.M., Jeganathan, C., Dash, J., Atzberger, C. 2012. Inter-comparison of four models for smoothing satellite sensor time-series data to estimate vegetation phenology. Remote Sensing of Environment 123, 400-417. https://doi.org/10.1016/j.rse.2012.04.001.

Atzberger, C., Eilers, P.H.C. 2011. A time series for monitoring vegetation activity and phenology at 10-daily time steps covering large parts of South America. Int. J. Digit. Earth 4, 365-386. https://doi.org/10.1080/17538947.2010.505664.

Baldi, G., Guerschman, J.P., Paruelo, J.M. 2006. Characterizing fragmentation in temperate South America grasslands. Agric. Ecosyst. Environ. 116, 197-208. https://doi.org/10.1016/j. agee.2006.02.009.

Baldi, G., Nosetto, M.D., Aragón, R., Aversa, F., Paruelo, J.M., Jobbágy, E.G. 2008. Long-term satellite data sets: evaluating their ability to detect ecosystem functional changes in South America. Sensors 8, 5397-5425. https://doi.org/10.3390/s8095397.

Barnston, A.G., Tippett, M.K. 2013. Predictions of Nino3.4 SST in CFSv1 and CFSv2: a diagnostic comparison. Climate Dynamics 41, 1612-1633. https://doi.org/10.1007/s00382-013-1845-2.

Bertin, R.I. 2008. Plant phenology and distribution in relation to recent climate change. Journal of the Torrey Botanical Society 135, 126-146. https://doi.org/10.3159/07-RP-035R.1.

Blanco, P.D., Colditz, R.R., López Saldaña, G., Hardtke, G.L.A., Llamas, R.M., Mari, N.A., Fischer, A., et al. 2013. A land cover map of Latin America and the Caribbean in the framework of the SERENA project. Remote Sensing of Environment 132, 13-31. https://doi. org/10.1016/j.rse.2012.12.025.

Broich, M., Huete, A., Tulbure, M.G., Ma, X., Xin, Q., Paget, M., Restrepo-Coupe, N., Davies, K., Devadas, R., Held, A. 2014. Land surface phenological response to decadal climate variability across Australia using satellite remote sensing. Biogeosciences 11, 5181-5198. https://doi.org/10.5194/bg-11-5181-2014.

Cabello, J., Paruelo, J.M. 2008. La teledetección en estudios ecológicos. Ecosistemas 17, 1-3.

Cong, N., Wang, T., Nan, H., Ma, Y., Wang, X., Myneni, R.B., Piao, S. 2013. Changes in satellitederived spring vegetation green-up date and its linkage to climate in China from 1982 to 2010: a multimethod analysis. Global Change Biology 19, 881-891. https://doi.org/10.1111/ gcb.12077. 
Dai, J., Wang, H., Ge, Q. 2013. The spatial pattern of leaf phenology and its response to climate change in China. International Journal of Biometeorology 58, 521-528. https://doi. org/10.1007/s00484-013-0679-2.

Dessay, N., Laurent, H., Machado, L.A.T., Shimabukuro, Y.E., Batista, G.T., Diedhiou, A., Ronchail, J. 2004. Comparative study of the 1982-1983 and 1997-1998 El Niño events over different types of vegetation in South America. International Journal of Remote Sensing 25, 4063-4077. https://doi.org/10.1080/0143116031000101594.

Durbin, J., Watson, G.S. 1951. Testing for serial correlation in least squares regression. II. Bometrika 38, 159-178. https://doi.org/10.1093/biomet/38.1-2.159.

Forján, H., Manso, L. 2012. La secuencia de cultivos. In: H. Forján, L. Manso (Eds.), Rotaciones y secuencias de cultivos en la región mixta cerealera del centro-sur bonaerense: 30 años de experiencias. Ediciones INTA, Tres Arroyos, Argentina, pp. 25-34.

Friedl, M., Henebry, G.M., Reed, B.C., Huete, A., White, M.A., Morisette, J.T., Nemani, R., Zhang, X., Myneni, R. 2006. Land surface phenology, A community white paper requested by NASA. https://cce.nasa.gov/mtg2008_ab_presentations/Phenology_Friedl_whitepaper. pdf (accessed 13 November 2018).

Gandini, M., Lara, B., Moreno, L., Cañibano, A., Gandini, P. 2019. Trends in fragmentation and connectivity of Paspalum quadrifarium in the Buenos Aires province, Argentina. PeerJ 7 , e6450. https://doi.org/10.7717/peerj.6450.

Garreaud, R.D., Vuille, M., Compagnucci, R., Marengo, J. 2009. Present-day South American climate. Palaeogeography, Palaeoclimatology, Palaeoecology 281, 180-195. https://doi. org/10.1016/j.palaeo.2007.10.032.

Glade, F.E., Miranda, M.D., Meza, F.J., van Leeuwen, W.J.D. 2016. Productivity and phenological responses of natural vegetation to present and future inter-annual climate variability across semi-arid river basins in Chile. Environ. Monit. Assess. 188, 676. https://doi.org/10.1007/ s10661-016-5675-7.

Guerschman, J.P., Paruelo, J.M., Burke, I. 2003. Land use impacts on the Normalized Difference Vegetation Index in temperate Argentina. Ecol. Appl. 13, 616-628. https://doi. org/10.1890/1051-0761(2003)013[0616:LUIOTN]2.0.CO;2.

Guevara-Ochoa, C., Lara, B., Vives, L., Zimmermann, E., Gandini, M. 2018. A methodology for the characterization of land use using medium-resolution spatial images. Revista Chapingo Series Ciencias Forestales y del Ambiente 24, 207-218. https://doi.org/10.5154/r. rchscfa.2017.10.061.

Helman, D. 2018. Land surface phenology: what do we really "see" from space? Science of the Total Environment 618, 665-673. https://doi.org/10.1016/j.scitotenv.2017.07.237.

Helsel, D.R., Hirsch, R.M. 2002. Statistical methods in water resources. USGS, Reston Virginia, USA.

Horning, N., Robinson, J., Sterling, E., Turner, W., Spector, S. 2010. Remote Sensing for Ecology and Conservation: a handbook of techniques. Oxford Uni. ed., New York.

Hou, W., Gao, J., Wu, S., Dai, E. 2015. Interannual variations in growing-season NDVI and its correlation with climate variables in the southwestern Karst Region of China. Remote Sensing 7, 11105-11124. https://doi.org/10.3390/rs70911105.

Intergovernmental Panel on Climate Change (IPCC). 2013. Working Group I Contribution of the Fifth Assessment Report. Climate change 2013: the physical science basis. http://www.ipcc. ch/report/ar5/wg1/.

Jönsson, P., Eklundh, L. 2004. Timesat - a program for analyzing time-series of satellite sensor data. Computer \& Geosciences 30, 833-845 https://doi.org/10.1016/j.cageo.2004.05.006.

Kuenzer, C., Dech, S., Wagner, W. 2015. Remote Sensing Time Series: revealing land surface dynamics. Springer. ed. https://doi.org/10.1007/978-3-319-15967-6. 
Lara, B., Gandini, M. 2014. Quantifying the land cover changes and fragmentation patterns in the Argentina Pampas, in the last 37 years (1974-2011). Geofocus 14, 163-180.

Lara, B., Gandini, M. 2016. Assessing the performance of smoothing functions to estimate land surface phenology on temperate grassland. Int. J. Remote Sens. 37, 1801-1813. https://doi. org/10.1080/2150704X.2016.1168945.

Lara, B., Gandini, M., Gantes, P., Matteucci, S.D. 2018. Regional patterns of ecosystem functional diversity in the Argentina Pampas using MODIS time-series. Ecological Informatics 43, 6572. https://doi.org/10.1016/j.ecoinf.2017.11.004.

Lieth, H. 1974. Phenology and seasonality modeling. Springer, New York. https://doi. org/10.1007/978-3-642-51863-8.

Luo, X., Chen, X., Xu, L., Myneni, R., Zhu, Z. 2013. Assessing performance of NDVI and NDVI3g in monitoring leaf unfolding dates of the deciduous broadleaf forest in northern China. Remote Sensing 5, 845-861 https://doi.org/10.3390/rs5020845.

Manuel-Navarrete, D., Gallopin, G.C., Blanco, M., Díaz-Zorita, M., Ferraro, D.O., Herzer, H., Laterra,P., Murmis, R., Podesta, G.P., Rabinovich, J., Satorre, E.H., Torres, F., Viglizzo, E.F. 2009. Multi-causal and integrated assessment of sustainability: the case of agriculturization in the Argentine Pampas. Environ. Dev. Sustain. 11, 621-638. https://doi.org/10.1007/ s10668-007-9133-0.

Matteucci, S.D. 2012. Ecorregión Pampa. In: J.H. Morello, S.D. Matteucci, A. Rodríguez, M. Silva (Eds.), Ecorregiones y Complejos Ecosistémicos Argentinos. Buenos Aires, pp. 391446.

Melendez-Pastor, I., Navarro-Pedreño, J., Koch, M., Gómez, I., Hernández, E.I. 2010. Landcover phenologies and their relation to climatic variables in an anthropogenically impacted mediterranean coastal area. Remote Sens. 2, 697-716. https://doi.org/10.3390/rs2030697.

Mestelan, S.A., Ramaglio, J.C. 2011. Características, distribución y usos de los suelos del partido de Azul. In: E. Requesens (Ed.), Bases agroambientales para un desarrollo sustentable del partido de Azul. Universidad Nacional del Centro de la provincia de Buenos Aires. Facultad de Agronomía, pp. 61-75.

Monteith, J.L. 1981. Climatic variation and the growth of crops. Quaterly J. R. Meteorol. Soc. 107, 749-774. https://doi.org/10.1256/smsqj.45401.

Müller, O., Berbery, E., Alcaraz-Segura, D., Ek, M. 2014. Regional model simulations of the 2008 drought in southern South America using a consistent set of land surface properties. J. Clim. 27, 6754-6778. https://doi.org/10.1175/JCLI-D-13-00463.1.

Nemani, R., Keeling, C., Hashimoto, H., Jolly, W., Piper, S.C., Tucker, C.J., Myneni, R.B., Running, S.W. 2003. Climate-driven increases in global terrestrial net primary production from 1982 to 1999 . Science $300,1560-1563$. https://doi.org/10.1126/science.1082750.

Paruelo, J.M. 2008. La caracterización funcional de los ecosistemas mediante sensores remotos. Ecosistemas 17, 4-22.

Paruelo, J.M., Garbulsky, M.F., Guerschman, J.P., Jobbágy, E.G. 2004. Two decades of Normalized Difference Vegetation Index changes in South America: identifying the imprint of global change. International Journal of Remote Sensing 25, 2793-2806. https://doi.org/10 $.1080 / 01431160310001619526$.

Paruelo, J.M., Jobbágy, E.G., Sala, O.E. 2001. Current distribution of Ecosystem Functional Types in temperate South America. Ecosystems 4, 683-698. https://doi.org/10.1007/s10021-001-0037-9.

Paruelo, J.M., Texeira, M., Staiano, L., Mastrángelo, M., Amdan, L., Gallego, F. 2016. An integrative index of Ecosystem Services provision based on remotely sensed data. Ecological Indicators 71, 145-154. https://doi.org/10.1016/j.ecolind.2016.06.054.

Podestá, G.P., Messina, C.D, Grondona, M.O., Magrin, G.O. 1999. Associations between grain crop yields in central-eastern Argentina and El Niño-Southern Oscillation. Journal of Applied 
Meteorology 38, 1488-1498. https://doi.org/10.1175/1520-0450(1999)038<1488:ABGCYI> 2.0.CO;2.

Reed, B.C., Schwartz, M.D., Xiangming, X. 2009. Remote sensing phenology: status and the way forward. In: A. Noormets (Ed.), Phenology of Ecosystem Processes, Springer, New York, pp. 231-246. https://doi.org/10.1007/978-1-4419-0026-5_10.

Rojas, M.C., Vázquez, P.M., Verdier, M., Noseda, R. 2011.Componentes del paisaje que favorecen la aparición de carbunco en la Pampa Deprimida (provincia de Buenos Aires, Argentina). Revue Scientifique et Technique de l' Office International Des Epizzoties 30, 897-909. https:// doi.org/10.20506/rst.30.3.2086.

Rouse, J.W., Haas, R.H, Schell, J.A., Deering, D.W. 1973. Monitoring the vernal advancement and retrogradation (green wave effect) of natural vegetation. Prog. Rep. RSC 1978-1, Remote Sensing Center, Texas A \& M Univ., College Station, 93 p. (NTIS No. E73-106393).

Salio, P.,Hobouchian, M.P., García Skabar, Y., Vila,D. 2015.Evaluation of high-resolution satellite precipitation estimates over southern South America using a dense rain gauge network. Atmospheric Research 163, 146-161. https://doi.org/10.1016/j.atmosres.2014.11.017.

Schmidt, M., Raupach, M., Briggs, P. 2010. Use of lagged time series correlations to relate climate drivers and vegetation response, in: Proceedings of the $15^{\text {th }}$ Australasian Remote Sensing and Photogrammetry Conference. pp. 1-14.

Solano, R., Didan, K., Jacobson, A., Huete, A. 2010. MODIS Vegetation Index User's Guide (MOD13 Series) C5. Vegetation Index and Phenology Lab, The University of Arizona.

Texeira, M., Oyarzabal, M., Pineiro, G., Baeza, S., Paruelo, J. 2015. Land cover and precipitation controls over long- term trends in carbon gains in the grassland biome of South America. Ecosphere 6, 196. https://doi.org/10.1890/ES15-00085.1.

Tucker, C.J. 1979. Red and photographic infrared linear combinations for monitoring vegetation. Remote Sensing of Environment 8, 127-150. https://doi.org/10.1016/0034-4257(79)90013-0.

van Leeuwen, W.J.D., Hartfield, K., Miranda, M., Meza, F.J. 2013. Trends and ENSO / AAO driven variability in NDVI derived productivity and phenology alongside the Andes mountains. Remote Sensing 5, 1177-1203. https://doi.org/10.3390/rs5031177.

Vazquez, P., Zulaica, L. 2013. Intensificación agrícola y pérdida de servicios ambientales en el partido de Azul (provincia de Buenos Aires) entre 2002-2011. Rev. Soc. Nat. 25, 543-556. https://doi.org/10.1590/S1982-45132013000300008.

Viglizzo, E.F., Frank, F.C., Carreño, L.V., Jobbágy, E.G., Pereyra, H., Clatt, J., Pincén, D., Ricard, M.F. 2011. Ecological and environment footprint of 50 years of agricultural expansion in Argentina. Global Change Biology 17, 959-973. https://doi.org/10.1111/j.1365-2486.2010.02293.x.

Viglizzo, E.F., Roberto, Z.E., Lértora, F., López Gay, E., Bernardos, J. 1997. Climate and land-use change in field-crop ecosystems of Argentina. Agriculture, Ecosystems and Environment 66, 61-70. https://doi.org/10.1016/S0167-8809(97)00079-0.

Vitousek, P.M., Mooney, H.A., Lubchenco, J., Melillo, J.M. 1997. Human domination of Earth's ecosystems. Science 277, 494-499. https://doi.org/10.1126/science.277.5325.494.

Wang, C., Cao, R., Chen, J., Rao, Y., Tang, Y. 2015. Temperature sensitive of spring vegetation phenology correlates to within-spring warming speed over the Northern Hemisphere. Ecological Indicators 50, 62-68. https://doi.org/10.1016/j.ecolind.2014.11.004.

Wang, Q., Tenhunen, J., Dinh, N.Q., Reichstein, M., Vesala, T., Keronen, P. 2004. Similarities in ground- and satellite-based NDVI time series and their relationship to physiological activity of a Scots pine forest in Finland. Remote Sensing Environment 93, 225-237. https://doi. org/10.1016/j.rse.2004.07.006.

Wang, Y., Huang, F. 2015. Identification and analysis of ecosystem functional types in the west of Songnen Plain, China, based on moderate resolution imaging spectroradiometer data. Journal of Applied Remote Sensing 9, 096096. https://doi.org/10.1117/1 .JRS.9.096096. 
Weiss, J.L., Gutzler, D.S., Allred, J.E., Dahm, C.N. 2004. Seasonal and inter-annual relationships between vegetation and climate in central New Mexico, USA. Journal of Arid Environment 57, 507-534. https://doi.org/10.1016/S0140-1963(03)00113-7.

Wolter, K., Timlin, M.S. 2011. El Niño/Southern Oscillation behaviour since 1871 as diagnosed in an extended multivariate ENSO index (MEI.ext). International Journal of Climatology 31, 1074-1087. https://doi.org/10.1002/joc.2336.

Zhang, Y., Song, C., Band, L.E., Sun, G., Li, J. 2017. Reanalysis of global terrestrial vegetation trends from MODIS products: Browning or greening? Remote Sensing of Environment 191, 145-155. https://doi.org/10.1016/j.rse.2016.12.018.

Zhao, M., Running, S.W. 2010. Drought-induced reduction in global terrestrial net primary production from 2000 through 2009. Science 329: 940-943. https://doi.org/10.1126/ science.1192666.

Zhou, J., Cai, W., Qin, Y., Lai, L., Guan, T., Zhang, X., Jiang, L., Du, H., Yang, D., Cong, Z., Zheng, Y. 2016. Alpine vegetation phenology dynamic over 16 years and its covariation with climate in a semi-arid region of China. Science of the Total Environment 572, 119-128. https://doi.org/10.1016/j.scitotenv.2016.07.206.

Zhu, L., Meng, J. 2015. Determining the relative importance of climatic drivers on spring phenology in grassland ecosystems of semi-arid areas. Int. J. Biometeorol. 5, 237-248. https://doi.org/10.1007/s00484-014-0839-z.

\section{Supplementary Material}

Table A1. Results of the regression between land surface phenological (LSP) metrics and Multivariate ENSO Index (MEI), and LSP metrics and accumulated precipitation. Mean slope regression coefficient represent changes in LSP metrics per $1 \mathrm{~mm}$ changed in accumulated precipitation and per 0.01 unit change in MEI values. SOS: start of the growing season, $i-N D V I$ : annual productivity, $t$-MAX: the timing of the annual maximum NDVI, and RREL: seasonality.

\begin{tabular}{|c|c|c|c|c|c|c|}
\hline $\begin{array}{l}\text { Climatic } \\
\text { variables }\end{array}$ & $\begin{array}{c}\text { Land surface } \\
\text { phenolog- } \\
\text { ical (LSP) } \\
\text { metrics }\end{array}$ & Slope & $\begin{array}{c}\text { Surface } \\
(\text { thousand } \\
\left.\mathbf{k m}^{2}\right)\end{array}$ & $\begin{array}{c}\text { Percentage of } \\
\text { total study area } \\
(\%)\end{array}$ & $\begin{array}{l}\text { Mean slope } \\
\text { regression } \\
\text { coefficient }\end{array}$ & $\begin{array}{l}\text { Percentage rate of } \\
\text { change with respect to } \\
\text { mean LSP metric }(\%)\end{array}$ \\
\hline \multirow{2}{*}{ MEI } & \multirow{4}{*}{ SOS } & Negative & 7.24 & 5.1 & -1.817 & -0.701 \\
\hline & & Positive & 17.17 & 12.1 & 2.213 & 0.854 \\
\hline \multirow{2}{*}{$\begin{array}{l}\text { Precipita- } \\
\text { tion }\end{array}$} & & Negative & 33.58 & 23.7 & -0.452 & -0.174 \\
\hline & & Positive & 13.16 & 9.3 & 0.444 & 0.171 \\
\hline \multirow{2}{*}{ MEI } & \multirow{4}{*}{ i-NDVI } & Negative & 15.23 & 10.7 & -0.0568 & -0.609 \\
\hline & & Positive & 33.52 & 23.6 & 0.0642 & 0.689 \\
\hline \multirow{2}{*}{$\begin{array}{l}\text { Precipita- } \\
\text { tion }\end{array}$} & & Negative & 12.91 & 9.1 & -0.0145 & -0.156 \\
\hline & & Positive & 40.31 & 28.4 & 0.0156 & 0.168 \\
\hline \multirow{2}{*}{ MEI } & \multirow{4}{*}{ t-MAX } & Negative & 8.54 & 6.0 & -0.504 & -0.135 \\
\hline & & Positive & 29.51 & 20.9 & 0.947 & 0.253 \\
\hline \multirow{2}{*}{$\begin{array}{l}\text { Precipita- } \\
\text { tion }\end{array}$} & & Negative & 34.46 & 24.3 & -0.529 & -0.141 \\
\hline & & Positive & 13.21 & 9.3 & 0.575 & 0.153 \\
\hline \multirow{2}{*}{ MEI } & \multirow{4}{*}{ RREL } & Negative & 21.13 & 14.9 & -0.0003 & -0.931 \\
\hline & & Positive & 20.46 & 14.5 & 0.0003 & 0.931 \\
\hline \multirow{2}{*}{$\begin{array}{l}\text { Precipita- } \\
\text { tion }\end{array}$} & & Negative & 42.97 & 30.4 & -0.00008 & -0.243 \\
\hline & & Positive & 8.42 & 5.9 & 0.00008 & 0.243 \\
\hline
\end{tabular}


Lara et al.

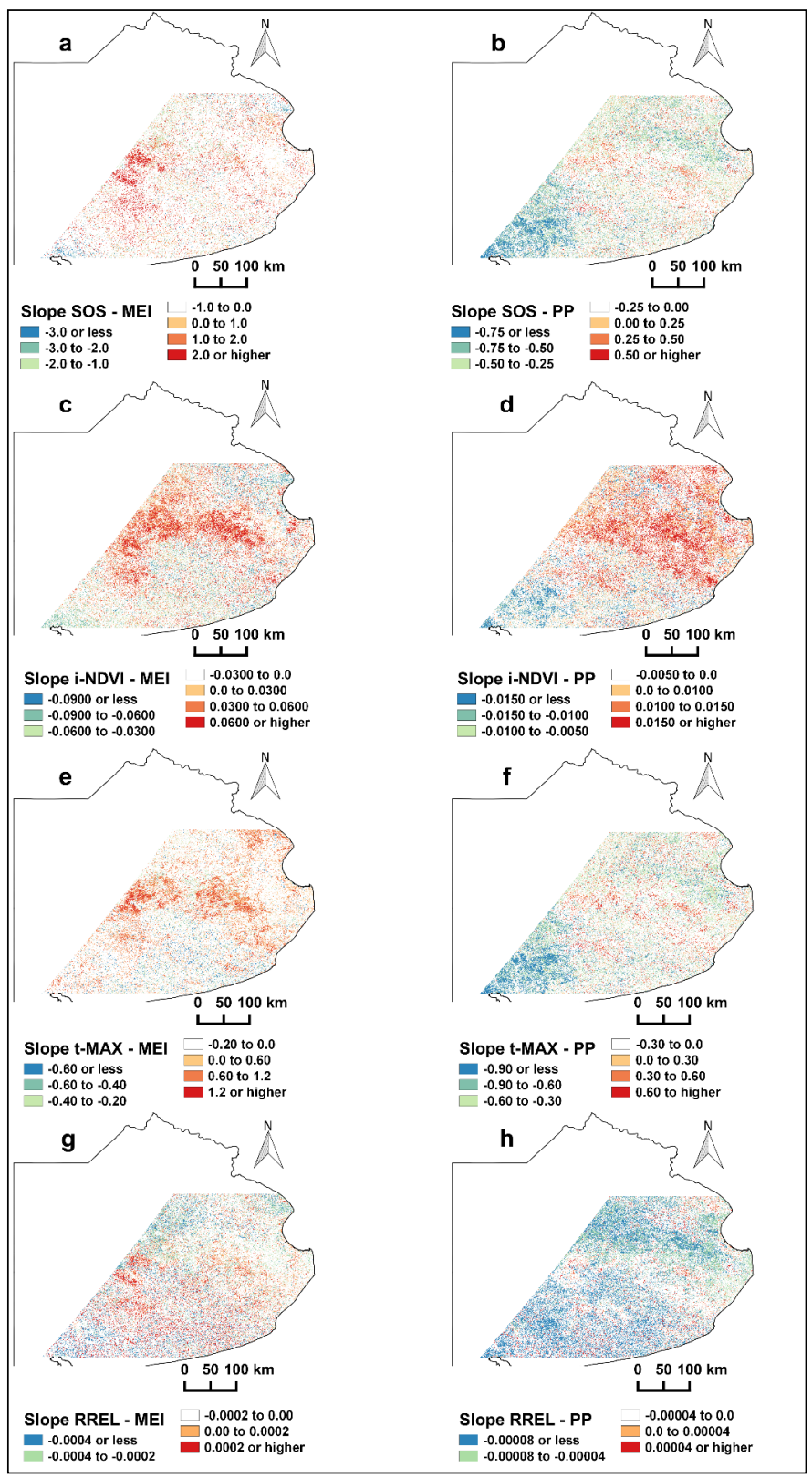

Figure A1. Relationships between land surface phenological (LSP) metrics and climatic variables expressed by the significant slopes obtained from each first order linear regression analysis. MEI: Multivariate ENSO Index, PP: accumulated precipitation, SOS: start of the growing season, $i-N D V I$ : annual productivity, $t$-MAX: the timing of the annual maximum NDVI, and RREL: seasonality. Slope regression coefficient represent changes in LSP metrics per $1 \mathrm{~mm}$ changed in accumulated precipitation and per 0.01 unit change in MEI values. 